Articles

http://dx.doi.org/10.15762/ZH.2018.53

JULIA MOŻDŻEŃ

(University Library in Toruń)

\author{
The Picture of the City of Gdańsk \\ in the Historiography From Beyond Gdańsk in the Late \\ Middle Ages and the Beginning of the Early Modern Period*
}

Key words: city in the Middle Ages and in the early modern period, chronicle, historiography, travel accounts

The analysis of the picture of every big city is an extensive and multifaceted issue. The case of Gdańsk, which, despite being frequently mentioned in the chronicles of the $15^{\text {th }}$ and $16^{\text {th }}$ centuries, was rarely addressed by scholars. The rich source material about how the city was perceived and described may be found in the chronicles of Gdańsk (particularly well preserved in this Prussian city) where the life of the city constitutes the focus of the narrative. However, historiographic works created beyond Gdańsk and mentioning this city only cursorily, but frequently (see below) also provide us with the abundance of information. Historians dealing with the analysis of the picture of this city in the written sources understand this term in a distinct way ${ }^{1}$. So far they have focused their attention on the manner in which the political history of the city and its inhabitants was presented; they have devoted less space to descriptions of the places they lived in. Important remarks concerning this political image of the history of Gdańsk presented in the historiography of the city (also in poetry and political songs) may be found in the study by Jolanta Dworzacz-

* The paper was written as part of the grant financed by Narodowe Centrum Nauki [the National Science Centre, Poland], titled "Municipal rulership in the Hanseatic cities of Prussia and Livonia in the Middle Ages", no. 2016/21/B/HS3/03099, carried out at the Faculty of History of Nicolaus Copernicus University. The Principal Investigator of the project is Prof. dr hab. Janusz Tandecki. The author is one of the investigators of the project.

${ }^{1}$ I apply the assumptions of the methodology of Hans-Werner GoETz, Wahrnehmungsund Deutungsmuster als methodisches Problem der Geschichtswissenschaft, Das Mittelalter, Bd. 8: 2003, H. 2, pp. 23-33. See more: Julia MożDżEŃ, Przedstawianie świata przez kronikarzy gdańskich na przełomie XV i XVI wieku (Roczniki Towarzystwa Naukowego w Toruniu, vol. 95, no. 2), Toruń 2016, pp. 13-14. 
kowa of $1962^{2}$. The problem was not analysed completely in this work as the author referred to the question marginally. The picture of the history of the city is revealed incidentally in Dworzaczkowa's book. The first complete manner of presenting political events connected with the history of Gdańsk (only in Polish historiography) was analysed in 1998 by Jadwiga Krzyżaniakowa ${ }^{3}$. In 2003 Dariusz Kaczor discussed the issue of how Gdańsk and its history had been perceived in the chronicle written by the Dominican Martin Gruneweg $(1562 \text { - ca. } 1618)^{4}$; earlier the problem had been briefly discussed by the editor of the chronicle Almut Bues ${ }^{5}$. The picture of the municipal space of Gdańsk in private accounts of inhabitants of Gdańsk writing at the turn of the $15^{\text {th }}$ and $16^{\text {th }}$ centuries and the manner in which they had perceived the history of their city was addressed by Julia Możdżeń ${ }^{6}$ in 2016 . However, none of the sources provides the complete treatment of the issue.

The source material available is much more extensive ${ }^{7}$. So far in the analysis of the narrative sources concerning Gdańsk neither regional historiography (created by the Teutonic Order, Pomeranian chroniclers ${ }^{8}$ and monastic chroni-

${ }^{2}$ Jolanta Dworzaczkowa, Dziejopisarstwo gdańskie do połowy XVI wieku, Gdańsk 1962, pp. 136-180.

${ }^{3}$ Jadwiga KrzyżaniakowA, Gdańsk w średniowiecznej historiografii polskiej, [in:] Gdańsk średniowieczny $w$ świetle najnowszych badań archeologicznych i historycznych, ed. Henryk PANER, Gdańsk 1998, pp. 133-142.

${ }^{4}$ Dariusz Kaczor, Orbis Gedanense. Wizja Gdańska w kronice dominikanina Martina Grunewega (XVI w.), [in:] Dominikanie. Gdańsk - Polska - Europa. Materiały z konferencji międzynarodowej pt. „Gdańskie i europejskie dziedzictwo. Zakon dominikanów w dziejach Gdańska”, ed. Dariusz Aleksander Dekański, Andrzej GoŁembnik, Marek Grubka, Gdańsk-Pelplin 2003, pp. 549-569.

${ }^{5}$ Die Aufzeichnungen des Dominikaners Martin Gruneweg (1562 - ca. 1618) über seine Familie in Danzig, seine Handelsreisen in Osteuropa und sein Klosterleben in Polen, Bd. 4: Einleitung, Beilagen, Register, ed. Almut Buss, Warszawa 2008, pp. 1537-1545.

${ }^{6}$ J. Możdżeń, Przedstawianie, pp. 91-252.

${ }^{7}$ Preliminary information may be obtained in the bibliography of Gdańsk w literaturze, but it does not exhaust the subject matter, particularly in reference to foreign chronicles - Gdańsk $w$ literaturze. Bibliografia od roku 997 do dzisiaj, vol. 1: Około 998-1600, ed. Zofia TylewskAOstrowska, Dagmara Binkowska, Gdańsk 2009.

${ }^{8}$ During the preparation of this article two main Pomeranian chronicles were used, which embrace the history of Western Pomeranian Pomerania by Johann BugENHAgEN (1485-1558) Johannes Bugenhagens Pomerania, ed. Otto Heinemann, Stettin 1900. The other chronicle is the work Thomas Kantzow (ca. 1505-1542) - idem, Pomerania, eine pommersche Chronik aus dem sechzehnten Jahrhundert, Bd. 1, ed. Georg Gaebel, Stettin 1908; Des Thomas Kantzow Chronik von Pommern in hochdeutscher Mundart, Bd. 1-2, ed. Georg GaEbeL, Stettin 1897-1898. The complete translation into Polish - Thomas Kantzow, Pomerania. Kronika pomorska z XVI wieku, vol. 1-2, trans. Kszysztof GoŁda, ed. Tadeusz BiAŁecki, Edward Rymar, Szczecin 2005. Records about Gdańsk are plentiful and deserve separate treatment as they refer mainly to political issues. 
clers $^{9}$ ) nor foreign historiography has been taken into account. The preserved source base is too extensive to be analysed within the scope of one article. I shall be interested in the criteria according to which the 'city character' of Gdańsk was defined and evaluated. It is those two factors that determined the fact of Gdańsk being considered to be the city in the strict sense. The most interesting material is provided in reference to this subject matter by foreign chronicles ${ }^{10}$, written by visitors from other countries, who made judgements and generated comparisons with other cities they had visited. The choice of this group of sources was determined by the fact that they had been totally omitted in the earlier research concerning the image of Gdańsk.

I shall also use travel accounts as they are characterized by the annalistic narrative style. As a result of the analysis I shall indicate the elements which in the eyes of the writers determined the 'municipal character' of the city or told about the quality of life in the centre and how attractive it was for visitors. The picture changed throughout the $15^{\text {th }}$ and $16^{\text {th }}$ centuries. Chroniclers travelling in Prussia compared Gdańsk to Torun. The comparison of the descriptions of those two cities allows us to grasp the dynamics of the development of Gdańsk in the $15^{\text {th }}$ century, which was noticed by the writers.

The choice of chronology was determined by the condition and nature of the source base. The war between Gdańsk and King Stephen Báthory in the years 1576-1577 occupies a separate place in the historiography of the second half of the $16^{\text {th }}$ century. Those events entailed the creation of the series of chronicles, the analysis of which goes beyond the scope of this article. Thus, the final caesura of the deliberations shall be the war mentioned above.

The first references to the appearance of the city of Gdańsk and information evaluating it as the centre of trade and life are found in the chronicles of the beginning of the $15^{\text {th }}$ century. Older historiographic sources referring to the city, such as the chronicle of Detmar, the Franciscan from Lübeck (died 1395) and his followers only mention briefly the political and commercial activity of Gdańsk's merchants and the city authorities ${ }^{11}$, but they fail to refer to it

${ }^{9}$ The manner in which Gdańsk was described in Kronika Oliwska written in the Cistercian monastery until 1352 was discussed by Błażej Śliwiński in the introduction to the Polish edition of the chronicle - Kronika Oliwska. Źródło do dziejów Pomorza Wschodniego z połowy XIV wieku, trans. Dominika Pietriewicz, ed. Błażej Śliwiński, Malbork 2008. In the chronicle Gdańsk is mentioned marginally, mostly in reference to arrogant burghers who struggled with the monastery - ibid., pp. 16-17.

${ }^{10}$ Here I refer to sources written beyond Prussia.

${ }^{11}$ Chronik des Franciscaner Lesemeisters Detmar, nach der Urschrift und mit Ergänzungen aus andern Chroniken, ed. Ferdinand Heinrich Grautoff, Th. 1, Hamburg 1829, p. 191; Th. 2, Hamburg 1830, pp. 152, 194, 228, 231, 241, 251, 268, 315, 353. 
as the municipal centre as such. The reasons for the situation may be found in the fact that the chronicle was to serve as an official document only.

Gilbert de Lannoy (1386-1462) of Burgundy, a traveller and diplomat ${ }^{12}$, the chamberlain of Duke Philip the Good (1419-1467) did not devote much space to the appearance of Gdańsk, either. He visited Prussia three times originally taking part in Teutonic military expeditions against Lithuania in 1413 and 1414; later, he held diplomatic positions as an envoy of Burgundy. In 1421 he spent some time at the court of Grand Master Michael Küchmeister (1414-1422) and Polish King Władysław Jagiełło (1386-1434) ${ }^{13}$. In 1413 he arrived in Prussia by sea "to a certain port and closed city called Gdańsk, through which the Vistula River flows to the sea; the port is actually referred to as the Vistula estuary (Polish: Wisłoujście) from the name of this river" ${ }^{14}$. The closed city should be understood as fully fortified as it has also been the case with Chełmno ${ }^{15}$, Kalisz, Swidnica ${ }^{16}$ and the Masovian town of Pułtusk, during the siege of which he acquired the knight's belt in $1413^{17}$. The opposite term was the unclosed town with wooden fortifications, which was often referred to such towns as "poorly developed" Trakai and "long and narrow" Vilnius ${ }^{18}$. In the period of the battle of Grunwald the Gdańsk fortifications were extended and several gates were modernized ${ }^{19}$. Gilbert de Lannoy stayed in Gdańsk very

${ }^{12}$ The literature devoted to the life of Gilbert de Lannoy and his biography is very rich. It is completed and sorted out by Andrzej NiEwiński - idem, Podróżnik i król. Gilbert de Lannoy na dworze Władysława Jagiełly, Roczniki Humanistyczne, vol. 61: 2013, no. 2, pp. 2539; Hain REBAS, Die Reise des Ghillebert de Lannoy in den Ostseeraum 1413/14. Motive und Begleitumstände, Hansische Geschichtsblätter, Jg. 101: 1983, pp. 30-42.

${ }^{13}$ Marek Radoch, Ziemie pruskie w oczach Gilberta de Lannoy, Komunikaty MazurskoWarmińskie, 2005, no. 4, p. 483.

${ }_{14}$ The fragments concerning Prussia were copied to: Aus den Voyaiges de Gilbert de Lannoy 1412 ff., ed. Ernst Strehlke, [in:] Scriptores rerum Prussicarum. Die Geschichtsquellen der preussischen Vorzeit. Bis zum Untergange der Ordensherrschaft, Bd. 3, ed. Theodor HinscH, Max Töppen, Ernst Strehlke, Leipzig 1866, s. 444 (further cit. Gilbert de Lannoy): “et puis arrivay en la terre et pais des seigneurs de Prusse a ung port et ville fermee nommee Danzike, parmy la quelle ville passay la riviere de le Wissel, qui va cheoir en la mer: et appelle on proprement le port de le Wissel apers le nom de la dite riviere". The fragments concerning Prussia and Poland in the Polish translation are printed in: Cudzoziemcy o Polsce. Relacje i opinie, vol. 1: Wiek X-XVII, ed. Jan GinTeL, Kraków 1971, pp. 76-77 (further cit. Cudzoziemcy). It is a reprint translated by Joachim Lelewel, Gilbert de Lannoy i jego podróże, Poznań 1844. Marek Radoch provides the new modern translation of the fragments devoted to Prussia, see: M. RADOCH, op.cit., pp. $473-484$.

${ }^{15}$ Gilbert de Lannoy, p. 449; Cudzoziemcy, p. 81 .

${ }^{16}$ Cudzoziemcy, p. 81.

${ }^{17}$ M. RADoch, op.cit., p. 478; Gilbert de Lannoy, p. 445.

${ }^{18}$ Cudzoziemcy, p. 79.

${ }^{19}$ For example Breite Thor and Anckerschmiede Thor. Marian Biskup, Kultura, [in:] Historia Gdańska, vol. 1: Do roku 1454, ed. Edmund CieślaK, Gdańsk 1978, pp. 449, 605. 
often, even during longer periods of winter (the turn of 1413 and 1414) when the navigation was impossible. Still, he did not devote much time and effort to Gdańsk. He only wrote that the city constituted a perfect base camp to effectuate further parts of the travel, or, on the contrary, a good place to return to after the travels to take the ship. Gdańsk was a kind of reference mark in Prussia. The distances between Gdańsk and other important Prussian cities were recorded, e.g. Malbork (7 miles), Königsberg (33 miles), Toruń (12 miles) ${ }^{20}$. However, Gdańsk lost this function when de Lannoy had got to know better the Prussian and Livonian territories. Gilbert de Lannoy preferred Toruń to Gdańsk. He visited Torun in 1414 and wrote: "I arrived in a very beautiful and rich fortified city and castle, the base of the convent and the commander's castle; it is called Torun and it is situated on the Vistula River"21. He also visited Elbląg, which he referred to as a "very beautiful small town"22 (he also considered Wrockaw to be a beautiful and rich city). According to de Lannoy, from among Prussian towns only Königsberg deserved to be called a "great city" ${ }^{23}$, but in fact it was smaller than Gdańsk with its 10,000 inhabitants ${ }^{24}$. In the year 1416 the size of the whole city complex of Gdańsk is estimated to have amounted to ca. 20,000 inhabitants - including 15,000 residents of the Main City of Gdańsk itself ${ }^{25}$. Having visited big European cities (such as Paris with its 100,000 inhabitants), Gilbert de Lannoy knew best what it meant for a city to be big. Prior to his arrival in Prussia in 1413, de Lannoy managed to visit Spain, where he took part in tournaments (1403), fought with the Moors in Castile (1407, 1411); he knew well Paris, Bourges and Orléans; he also went on a pilgrimage to the Holy Land (1401) and Compostella (1408) ${ }^{26}$. Thus, it may be concluded that he knew perfectly what the biggest and most beautiful cities of those times looked like. He regarded Gdańsk as a city of average beauty if we realize that the Church of Our Lady in Gdańsk did not start to be extended in a form of a hall church

${ }^{20}$ M. RADOCH, op.cit., pp. 475-476.

${ }^{21}$ Gilbert de Lannoy, p. 449: "Sy men allay parmy le pais de Prusse, tant que je vins a une moult belle et riche ville fermee et chastel, couvent et commanderie nommee Thore, situee sur la riviere de le Wisle, [...]"; Cudzoziemcy, p. 80. Comp. M. Radoch, op.cit., p. 481.

${ }^{22}$ Gilbert de Lannoy, p. 445: "et revins Melvinghe, qui est tres belle petite ville et commanderie assise sur deux rivieres"; Cudzoziemcy, p. 77.

${ }^{23}$ Gilbert de Lannoy, p. 445; Cudzoziemcy, p. 77.

${ }^{24}$ Fritz Gause, Die Geschichte der Stadt Königsberg in Preussen, Bd. 1, Köln-Weimar-Wien 1996, p. 119.

${ }^{25}$ Joachim Zdrenka discusses various opinions of scholars about the subject matter, see: Joachim Zdrenka, Główne, Stare i Młode Miasto Gdańsk i ich patrycjat w latach 1342-1525, Toruń 1992, p. 79.

${ }^{26}$ M. RADOCH, op.cit., p. 473. 
until $1416^{27}$, before which time it was the Teutonic castle that had dominated the city's panorama. His opinion was shared by other people.

Both cities were compared to each other many times. Aeneas Silvius Piccolomini, from the year 1458 - Pope Pius II, expressed a slightly different opinion about the cities in his work De ritu, moribus et conditione Germaniae ${ }^{28}$. He describes Prussia as part of the German territory (the so called Nova Germania) ${ }^{29}$, and he also refers to towns and cities. He writes: "In Prussia the most important city is Gdańsk. Its territory extends on the sea and on the land; during a wartime it is capable of providing 50,000 soldiers. Its trade ships are numerous on the Baltic Sea". Next, he adds: "Torun also is a famous town; it is situated on the Vistula River and used to belong to Sarmatia" ${ }^{30}$. The chronicler underlined that Toruńs geographical location was inferior to Gdańsk, but still it was a magnificent town. This description of 1457-1458 reflects the altered economic-political situation between both cities. Gdańsk was becoming an increasingly important city in political and economic terms, both at the sea and on the land. The number of soldiers and the city's capability to feed so many of them was to impress the reader. In this way, the scales tipped in Gdańsk's favour.

At the same time, several years after the outbreak of the Thirteen Years' War Jan Długosz in his Chorografia referred to Gdańsk as the "city not really great", but famous owing to its location and trade ${ }^{31}$. According to Długosz, the

${ }^{27}$ M. Biskup, Kultura, p. 607.

${ }^{28}$ Aeneae Sylvii Piccolominei (Pontificis Pii II.) opera, quae extant omnia, nunc demum post corruptissimas editiones summa diligentia castigata et in unum corpus redacta. His quoque accessit gnomologia ex omnibus Sylvii operibus collecta, et index copiosissimus, Basel 1571, pp. 1034-1986.

${ }^{29}$ See more about the concept - Udo ARNOLD, Deutschordenshistoriographie im Deutschen Reich, [in:] Die Rolle der Ritterorden in der mittelalterlicher Kultur, ed. Zenon Hubert NowAK, Torun 1985, p. 81. He did a similar thing in the description of Prussia in De Europa, where Gdańsk is mentioned only once as the place where the Vistula flows into the Baltic Sea: "But it [i.e. Vistula - J.M.] runs through the whole length of Prussia from the town of Torun to Gdańsk, where it flows into the Baltic" - Aeneas Silvius Piccolomini, Europe (c. 1400-1458), trans. Robert Brown, ed. Nancy BisAHA, Washington 2013, p. 149.

${ }^{30}$ Aeneae Sylvii Piccolominei (Pontificis Pii II.) opera, p. 1054: "Inter Prutenos notissima Gendani fama est, terra marique potentis oppidi, cuius populum ad praelium exiens haud minus quam quinquaginta milia bellatorum educere fuerunt, naues eius in baltheo pelago complures negotiatorum nauigant. Est \& Tornetis oppidi haud uulgare nomen, quamuis supra uiscellam ad Sarmatas olim pertinuerit”.

${ }^{31}$ Ioannis Dlugosii Annales seu Cronicae incliti Regni Poloniae, ed. curavit et introd. scripsit Jan DĄBRowski, textum recensuit atque praefatione instruxit WANDA SEMkowicz-ZarembiNA; comment. Krystyna Pieradzka, Bożena Modelska-StrzeleckA, Lib. 1, Varsaviae 1964, p. 114: “[...] opidum Gdansk, nedum aput Polonos, verum aput ceteras gentes et naciones vicinas memorabile, haud magnum quidem opidum, sed frequenti emporio celebre, quod multarum rerum merces in illud flumine Visla, qui illic hostio uno ex tribus miscetur equori Occeano Sarmatico, magnarum gencium fines contingens, quarum commercia illic terra, undis et pelago 
city's location was not particularly beneficial for it, which he underlined in his description of the city's siege in 1433 - "it was easy to attack it from above", which means from Biskupia Górka [Bishop's Hill] located opposite the city ${ }^{32}$. Gdańsk did not impress Długosz, which is reflected in his account concerning the stay of King Casimir IV Jagiellon in Gdańsk in 1457, which he wrote as a member of the king's retinue ${ }^{33}$. Despite spending over a month in Gdańsk from April to May $1457^{34}$, he did not pay much attention to the city concentrating almost exclusively on the description of how impressed inhabitants of Gdańsk had been by the splendour of the king's entourage. The description of Gdańsk seems even more modest if we compare it with the description of Torun, which he visited at the same time: "the city has beautiful buildings with shining roof tiles, which makes it look so magnificent that no other city can compete with it in terms of the beauty of the location and the splendour of its appearance"35.

The opinions of Gilbert de Lannoy and Jan Długosz probably reflect the actual condition of Gdańsk, the architectural heyday of which took place after the Thirteen Years' War (1454-1466) ${ }^{36}$.The records of Gdańsk's skipper Casper

frequenti et mutuo usu ex variis regionibus contrahuntur". Julia MożDżEŃ, Estetyka i obronność miast w narracji Roczników Jana Dlugosza, [in:] Jan Dlugosz. 600-lecie urodzin. Region - Polska - Europa w jego twórczości, ed. Jacek MAciejewski, Piotr OLIŃski, Waldemar RozynKowSKI, Sławomir ZoNenberG, Toruń-Bydgoszcz 2016, pp. 95-96.

${ }^{32}$ Joannis Dlugossii Annales seu Cronicae incliti Regni Poloniae, Lib. 11: 1413-1430, ed. Jerzy Wyrozumski, Danuta Turkowska, Stanisław Andrzej Sroka, Varsaviae 2001, p. 95: "Postquam vero ad Gdansk perventum est, quatuor diebus ibi stativa habita sunt et civitas tormentorum et bombardarum percussione (facilis enim ex monte in illam erat proieccio) plurimum quassata. Portus eciam maris, qui trabibus, sudibus et asseribus serratis ceterisque lignis, quo facilius navigia illic possent se recipere et securius consistere, communitus, per Polonos fuit violatus et in totum disiectus".

${ }^{33}$ Lata wojny trzynastoletniej $w$ „Rocznikach czyli kronikach” inaczej „Historii polskiej” Jana Długosza, (1454-1466), vol. 1, ed. Stefan Maria KuCZYŃsKi, Łódź 1964, pp. 87-88.

${ }^{34}$ Długosz arrived in Gdańsk on 16 April 1457 when the mercenaries were to paid their remuneration. He adored the entrance of King Casimir Jagiellon to the city on 1 May and was a witness of burghers' and knights' paying homage to the king on 9 May. In mid-May he arrived in Malbork. At the end of May he returned to Gdańsk and was a witness of signing the transumpt of the act of Grand Master and the Malbork convent for mercenaries. At the beginning of June he was again in Malbork. His subsequent visits in this city in August 1464 were short transits - nothing is known about longer stays. Marian Biskup, Działalność dyplomatyczna Jana Dlugosza w sprawach pruskich w latach 1454-1466, [in:] Dlugossiana. Studia historyczne w piećcsetlecie śmierci Jana Dlugosza, ed. Stanisław GawęDA, Kraków 1980, pp. 148, 159.

${ }^{35}$ Ioannis Dlugosii Annales seu Cronicae, Lib. 1, p. 114: "Item Thorvn, pulcherrimis edificiis et tectis ex cocto latere irradiantibus adeo memorabile, ut vix aliud sibi pulcritudine, situ et resplendencia exequari possit." See more: J. MożDżEŃ, Estetyka, pp. 93-94.

${ }^{36}$ The notes have also been examined by Grzegorz Bukala, Fortyfikacje Gdańska i ujścia Wisty 1454-1793. Studium z dziejów nowożytnej architektury militarnej, Sopot 2012, pp. 52-54, 57-58. 
Weinreich of the years 1461-1496, which include the description of the great development of the city (particularly its fortification in the $1480 \mathrm{~s}$ and $1490 \mathrm{~s}^{37}$ ), serve as the perfect evidence of the process. When Jan Długosz arrived in Gdańsk, the Church of Our Lady was being extended, its tower had only one storey - the remaining two were being built.

On the other hand, Albert Krantz $(1448-1517)^{38}$, a theologian and receiver from Hamburg, a Hanseatic chronicler, saw both cities - Gdańsk and Torun in a completely different light. In the years 1500-1504 in Hamburg ${ }^{39}$ he recorded the history of Wendish towns and Hansa in the work titled Wandalia. He relied on the older historiographic material, documents, letters and registries connected with assemblies of Hanseatic towns in which he took part ${ }^{40}$. The chronicle was published after his death in 1519 in Cologne ${ }^{41}$. Krantz belonged to outstanding figures - in 1480 he obtained a professorship at the Faculty of Liberal Arts, while in 1482 he was elected president of the University of Rostock. At the end of his life he held the position of a liquidator in Lübeck and Hamburg. Describing the history of Wendish towns he also devoted much space to the Prussians ${ }^{42}$, who, as he wrote, shared the border with the Baltic Wends and traded with 'our' merchants. 'The Prussians' spoke German very well, because they had forgotten their own Prussian language. He enumerated the Prussian seaside towns such as Königsberg, Malbork (as it may be reached by ship), Elbląg, and Gdańsk. The last city was referred to as herrliche, which means magnificent, and oberreichliche, which means very rich. "It is in this city that merchants carry out their trade, which we, the Wends, appreciate so highly. The city became rich at the expense of Torun, which is a town famous for its craft, but recently it has lost splendour for the benefit of Gdańsk, which captured the whole trade to itself" 43 . This statement reflects the actual process

${ }^{37}$ J. MożDżEŃ, Przedstawianie, pp. 193-197; eadem, Morze w zapiskach gdańskiego szypra Caspra Weinreicha $z$ lat 1461-1496, [in:] W epoce żaglowców. Morze od antyku do XVIII wieku, ed. Beata Możejкo, Ewa Bojaruniec-Król, Gdańsk 2016, pp. 69-80.

${ }^{38}$ Anette Cosanne, Krantz, Albert, [in:] Lexikon des Mittelalters, Bd. 5, München-Zürich 1991, col. 1475. See more: Ulrich Andermann, Albert Krantz. Wissenschaft und Historiographie um 1500, Weimar 1999.

${ }^{39}$ Heinrich ReINCKE, Albert Krantz als Geschichtsforscher und Geschichtsschreiber, [in:] Festschrift der Hamburgischen Universität ihrem Ehrenrektor Herrn Bürgermeister Werner von Melle zu 80. Geburtstag am 18. Oktober 1933 dargebracht, Glückstadt 1933, p. 124.

${ }^{40}$ The critical partition of Krantz's sources was published by Viljo Adolf Nordmann, Die Wandalia des Albert Krantz. Eine Untersuchung, Helsinki 1934 (Suomalaisen Tiedeakatemian Toimituksia. Annales Academiae Scientiarum Fennicae. Serja B. vol. 29, no. 3), pp. 103-260.

${ }^{41}$ See more: U. Andermann, op.cit., pp. 238-240.

${ }^{42}$ Comp. V. A. Nordmann, op.cit., pp. 210-211.

${ }^{43}$ Ibid., p. 193: "Preussen als ich angefangen / hat diese an See belegene Stadt erstlich Königsberg, [...] Fürther ligt die Stadt Elbingen / und die herrliche und oberreiche Stadt Dantzig / darin die Kauffleute stattlichen Handel haben / deren wir in künfftig / wenns die zeit gibt / zum 
of Toruń losing its significance as a trade mediator for the benefit of Gdańsk in the struggle to maintain the staple right ${ }^{44}$. Krantz expresses his admiration for the pace in which the city of Gdańsk developed and got rich ${ }^{45}$. Gdańsk also managed to soften social unrest in 1416 (Kogge's revolt) ${ }^{46}$. He wrote that until the year 1517 a man, who had been the witness of those events, was still alive. He also described the times when in the market place there had been only one building made of stone - the burgher house with the chamber of the council. Other houses had reed (ror) and bulrush (schliff) roofs and were covered with clay like peasants' houses. "Within one hundred years the city has become so powerful that it got rid of its superiors [Teutonic knights - J.M.] and surrendered to the Polish king, under whose control it has remained ever since" 47 . The political power of the city, which itself had chosen its ruler, was underlined. This picture of Gdańsk as a city which overcomes social conflicts constitutes a typical element of the description of towns from the burghers' point of view. As may be seen in Harald Bollbuck's analyses, this approach is particularly strong in Albert Krantz's descriptions of internal conflicts in Wendish towns ${ }^{48}$. He condemns the revolts against the municipal commune and the peace and considers the breach of God's commandments to be the reason for the conflict. This motif may be found also in Gdańsk's historio-

offtern gedencken werden. Besser hinein im Lande ligt an der Wixel die auch schöne Stadt Torn / welche ehemals trefflich Gewerbe geführet / aber jetzt / wie man sagt / sehr sol zurück steigen / drumb das ihr die Stadt Dantzig allen Handel abstricket / und an sich zeucht".

${ }^{44}$ The process was characterized by significant dynamics and changeability of the policy of Polish kings in relation to this question, including also its range (land routes and river rafting of goods to Gdańsk). Eventually, the staple right for Torun was abolished in 1537. The issue has been thoroughly discussed by Marian BIskup, Historia Torunia, vol. 2, part 1: U schyłku średniowiecza i w poczatkach odrodzenia (1454-1548), Toruń 1992, pp. 109-133.

${ }^{45}$ Heinrich Reincke pointed it out, idem, op.cit., p. 145. See more about Krantz's description of towns.

${ }^{46} \mathrm{Krantz}$ underlined the significance of freedom and lawfulness in the cities. As a warning to others he used to described revolts in Hanseatic towns: Rostock, Hamburg, Braunschweig and Stralsund. The reason for the development of the cities in this territory was lawfulness. See more: H. ReINCKE, op.cit., p. 145.

${ }^{47}$ It was not until 1600 that the work was translated into German. Albert KranTz, Wandalia oder Beschreibung Wendischer Geschichte, Lübeck 1600, p. 362: “[...] / welcher die Rathstube in einem gemeinen Bürgerhaus so damahls allein von Stein erbawet am Marckt gestanden / gehabt / und waren die andern häuser alle von Schliff und Rohr gedeckt / von Leimen geklebet nnd auff die alte Bawren manier erbawet gewesen. [...] Aus diesem geringen anfang ist die Stadt innerhalb hundert jahren zu solcher macht gedigen / das sie auch ire Herren / die Teutschen Ordens Brüder verstossen / und sich an den König zu Polen / unter dessen beschütz sie noch heute sein / ergeben [...]".

${ }^{48}$ Harald BolLBUCK, Geschichts- und Raummodelle bei Albert Krantz (um 1448-1517) und David Chytraeus (1530-1600). Transformationen des historischen Diskurses im 16. Jahrhunderts, (Imaginatio Borealis. Bilder des Nordens, Bd. 8), Frankfurt am Main 2006, pp. 86-87. 
graphy - the memorial of the Thirteen Years' written by the city's notary and envoy Johann Lindau (1454-1466) and the city's chronicle written by Gdańsk's merchants Bernt Stegmann (1528) ${ }^{49}$.

Under the influence of Krantz ${ }^{50}$, the famous cartographer and Hebrew scholar Sebastian Münster (1488-1552) ${ }^{51}$ wrote about Gdańsk. He had never been to Prussia or to Poland. However, the huge popularity of his work had to influence the opinion about Gdańsk in the eyes of the contemporaries. The first four issues of Sebastian Münster's Cosmographia, in the so-called short edition, were published in German in Basel in the years 1544, 1545, 1546 and 1548. They devoted only one sentence to this city and a symbolic woodcut panorama ${ }^{52}$. They are described in the section referring to German countries, just as Piccolomini did a hundred years earlier. In the first and second German-language edition of Cosmographia, Münster writes: "The City of Gdańsk, which is called Latin Gedanum or Dantiscum is a great craft city in Prussia and is now subject to the Polish king" "53. One could say, therefore, that he knew hardly anything about the city. The woodcut presented the ideal of a port city with powerful walls, towers and a wide entrance gate to the city. This image was placed in such a way that it illustrated at the same time two port cities described in this place - Gdansk and Königsberg. Their names were additionally written on the margins, with the name of the first one recorded at the level of the placed woodcut. However, it is difficult to say with certainty whether

${ }^{49}$ J. Możdżeń, Przedstawianie, pp. 56-60, 123-138.

${ }^{50}$ Münster acquired the knowledge about Poland and Prussia from Chronica Polonorum written by Maciej of Miechów (Cracoviae, 1519 and 1521) and De Borussiae antiquitatibus libri duo (Basileae, 1518) by Erasmus Stella, and the description of Wandalia by Albert Krantz Viktor Hantzsch, Sebastian Münster. Leben, Werk, wissenschaftliche Bedeutung, Leipzig 1898, p. 62. He obtained the images of the cities thanks to the cooperation with many well known artists, who made sketches for him, on the basis of which printing blocks were made - ibid., pp. 64-67.

${ }^{51}$ Claus Priesner, Münster Sebastian, [in:] Neue Deutsche Biographie, Bd. 18, Berlin, 1997, pp. 539-541; Peter H. Meurer, Cartography in the German Lands, 1450-1650, [in:] The History of Cartography, vol. 3: Cartography in the European Renaissance, part 2, ed. by David WoodWARD, Chicago-London 2007, pp. 1209-1213.

${ }^{52}$ The picture presents the symbolic image of the seaside town. The first edition of Cosmography, its translation and reprints were provided with the images of cities that had little to do with the reality. It was not until the second edition of 1550 that there appeared expandable elements of the panorama including more important buildings - V. HANTZsCH, op.cit., pp. 64-65; Friedrich BaCHMANn, Die alten Städtebilder. Ein Verzeichnis der graphischen Ortsansichten von Schedel bis Merian, Leipzig 1939, pp. 4-5.

${ }^{53}$ Cosmographia. Beschreibung aller Lender durch Sebastianum Munsterum in woelcher begriffen. Aller voelcker, Herrschafften, Stetten und namhaffiger flecken haerkomen. [...], Basel 1545, p. DI: "Die Stadt Dantzig, die man zu Latein Gedanum und auch Dantiscum nempt, ist ein groß gewerb stat in Preüssen und ist ietzu[n]t under dem künigreich Poland”. 
this was the author's intention or whether the layout of the text was a solution planned by the printer. This woodcut block was used in the 'short' version of Cosmographia many times in relation to other cities located on watercourses, among others Passau lying on three rivers ${ }^{54}$ or Lindau on Lake Constance ${ }^{55}$. Sebastian Münster continued his efforts to refine his work, constantly collecting materials through travel and exchange of letters. He corresponded with scholars and rulers of countries and cities, as well as representatives of the clergy, artists and travelers. He also used a whole range of the already existing chronicles and descriptions of the countries that interested him. Among them were the works of Maciej of Miechów and Erasmus Stella ${ }^{56}$, which were his main sources of knowledge about this part of Europe ${ }^{57}$. In the letters he sent out, the cartographer asked to send him sketches of towns and lands along with their descriptions. One of the few surviving letters of Sebastian Münster to the voivode of Sieradz, Sebastian Łaski, comes from 6 April 1548. We read in it that "I have not received any answer yet, neither from Gdańsk, called Dantiscum, nor from Königsberg in Prussia, which I also asked for in my letters" 58 . It is not known whether he received the answer at a later date. The scarcity of information about Gdańsk and the lack of the panorama of the city in the new edition of the chronicle contradicts this.

Münster's Cosmographia was an extremely important and attractive source of knowledge, also about Poland and Prussia. It had over 20 editions, and the so-called second extended edition of 1550 was translated within a few months into two more languages: Latin and French ${ }^{59}$. The description of Gdańsk in the

${ }^{54}$ Ibid., p. DXIIJ.

${ }^{55}$ Ibid., p. CCCCXVIIJ.

${ }^{56}$ They do not, however, include the descriptions of Gdańsk - Enee Silvii episcopi Senensis de situ et origine Pruthenorum, ed. Max Töppen, [in:] Scriptores rerum Prussicarum. Die Geschichtsquellen der preussischen Vorzeit. Bis zum Untergange der Ordensherrschaft, Bd. 4, ed. Theodor Hirsch, Max Töppen, Ernst Strehlke, Leipzig 1870 [further cit. SRP 4], p. 231; Ex Aeneae Sylvii historia Bohemica, ed. Theodor HIRsCH, [in:] SRP 4, p. 242; Maciej z Miechowa, Chronica Polonorum, Cracouiae 1521 (reprinted: Kraków 1986), p. CLV-CLVI, CCII. See more about Münster's sources - V. Hantzsch, op.cit., pp. 58-67.

${ }^{57}$ See the detailed description of Münster's knowledge about Poland: Wanda KonczyŃsKa, List Sebastjana Münstera do Stanisława Łaskiego i garść szczegółów w związku z jego Kosmografja, Kraków 1936, pp. 11-27.

${ }^{58}$ Cited after: ibid., p. 3 (the text in Latin): "sicut nec ex Gdano, quem Dantiscum vocant, et Regio Prussiae monte, quos etiam litteris meis sollicitavi". Comp. Karol BuczeK, Ein Beitrag zur Entstehungsgeschichte der „Kosmographie” von Sebastian Münster, Imago Mundi, Bd. 1: 1935, p. 39.

${ }^{59}$ The extended edition of 1550 was published in German, Latin and French with the circulation of 1800 copies each, which in total is 3600 volumes, including maps of Poland and Prussia. The reception of the book is beyond question. By 1628 it had been published 28 times (over 50,000 copies) - Stanisław Peliwo, Drzeworytowe mapy ziem polskich $w$ wydawnictwach książ- 
new edition of 1550 had been significantly expanded, it contained the entire paragraph devoted to this city. It should be noted that Gdańsk was the only Prussian city to be distinguished in this way. The symbolic woodcut disappeared and was replaced by the map of Prussia modeled on the map of Heinrich Zell of $1542^{60}$, on which Gdańsk was marked. In the edition of 1550, the last one he authorized, Gdańsk is presented as a rich and rapidly growing city ("sere in reichtumb und gewald auffgestigen"); as Münster wrote, the city had developed in a very short time, as a short time ago it had been "an imperceptible stain". Next, the chronicler quotes the re-written opinion from the Krantz' chronicle, where the town hall was not defined as stone but brick. Krantz also mentions a specific civilization leap of Gdańsk within one century - from homes made of clay and straw to a powerful center which had managed to get rid of the Teutonic rule. Münster added his opinion that other Prussian centers (he does not mention which ones) also wanted to follow in the footsteps of Gdańsk which had experienced considerable sufferings from the Teutonic Or$\operatorname{der}^{61}$. The description of the city in Cosmographia continued to be developed ${ }^{62}$, but without the participation of Münster, who died in 1552. In the last edition of 1628 the panorama of the city was added ${ }^{63}$.

Encouraged by the publishing success of Münster, the Polish poet and self-taught writer Marcin Bielski (i.e. Wolski, 1495-1575) wanted to publish a universal chronicle in Polish, written from the Polish perspective. In Kronika wszystkiego świata published for the first time in Cracow in $1551^{64}$, this his-

kowych XVI w., Warszawa 1991, (Studia i Materiały z Historii Kartografii, vol. 10), p. 69; Eckhart JÄGER, Prussia-Karten 1542-1810. Geschichte der kartographischen Darstellung Ostpreußens vom 16. bis zum 19. Jahrhundert. Entstehung der Karten - Kosten - Vertrieb. Bibliographischer Kata$\log$, Weißenhorn 1982, p. 47. In 1554 in Prague there appeared the Czech translation of the book, and in 1558 in Basel the book was published in Italian. See: Table 3: Wydania 'Kosmografii' Sebastiana Münstera, [in:] S. Peliwo, op.cit., pp. 71-72.

${ }^{60}$ E. JäGER, op.cit., p. 47.

${ }^{61}$ Sebastian MüNster, Cosmographia, Basel 1550, p. DCCCCXXVIII.

${ }^{62}$ In the Basel edition of 1628 there are 1.5 page and includes a totally different content, updated with the current political situation.

${ }^{63}$ Reprint of the edition of 1628, Sebastian Münster, Cosmographia, Basel 1628, Jubiläums-Ausgabe, ed. Karl-Heniz Burmeister, Bd. 2, [Lindau] 1982, pp. 1300-1301.

${ }^{64}$ The chronicle had three editions: 1551, 1554, 1564, each subsequent edition was extended. Before his death he worked on the fourth edition, which was finished and published in 1597 by his son Joachim. Marcin BIelski, Kronika wszytkiego świata na sześć wieków, monarchie cztery rozdzielona, z kosmografia i z rozmaitemi królestwy, tak pogańskiemi, żydowskiemi, jako i krześcijańskiemi, z Sybillami i proroctwy ich, po polsku pisana, z figurami, w której tė̇ żywoty cesarskie, papieskie i tych królów $z$ ich królestwy, asyryjskich, egipskich, żydowskich, greckich, perskich, tureckich, węierskich, czeskich i inych królów, książąt, jako inych przełożonych, od początku świata aż do tego roku, który się pisze 1551, sa wypisane, miedzy któremi też nasza Polska na ostatku z osobna jest wypisana, Kraków 1551; Kronika polska Marcina Bielskiego. Nowo przez Joach. Biel- 
torian transmits one version of the ethnogenetic myth that says that Gdańsk was founded along with other Wendish cities by the Polish monarch Wisimir, famous for his battles with the Danes. As Bielski writes, Wisimir left the sea coasts under his rule, on which he founded the following cities - Wismar, Lübeck and Gdańsk. The name Danczik was meant to commemorate the victory over the Danes. "At that time a small town, today a remarkable city, where merchants from all the Christian kingdoms come" ${ }^{35}$. Describing the contemporary times, he described Gdańsk as a "strong and defensive city"66.

The secretary of King Sigismund II Augustus, Marcin Kromer, who wrote in the same period of time, developed Polish history using the critical method. In 1577, an authorized version of his work was published in Cologne Polonia sive de situ, populis, moribus, magistratibus et republica regni Polonicai libri $d u o^{67}$, which he wrote down around 1558. It was to provide foreigners with some knowledge of this country, which is why he also described more important Prussian cities. Kromer presented Gdańsk as a city known for its port, shipyards and granaries, with huge walls, conveniently located at the mouth of the rivers, mainly the Vistula River. You can find here a wealth of goods from the West and North ${ }^{68}$, including Rhine, French, Spanish, Canary and Cretan wines, as well as spices, samite and silk, "which ruin the kingdom" of Poland ${ }^{69}$. The city is developing wonderfully "thanks to the diligence of citizens and for-

skiego syna jego wydana, Kraków 1597. See a more detailed description of all the editions - Dariusz ŚnıEżKo, Kronika wszytkiego świata Marcina Bielskiego. Pogranicze dyskursów (Rozprawy i studia Uniwersytetu Szczecińskiego, vol. 503), Szczecin 2004.

${ }^{65}$ Kronika polska Marcina Bielskiego (1597), p. 27.

${ }^{66}$ Ibid., p. 547.

${ }^{67}$ Martinus Cromer, Polonia sive de situ, populis, moribus, magistratibus et republica regni Polonici libri duo, Coloniae 1577. The work was written ca. 1558, but it remained as manuscript for almost 20 years and was circulated in many copies. The first edition took place in 1575 in Frankfurt on the Oder without the knowledge of the author - Henryk BARYCZ, Kromer Marcin, [in:] Polski slownik biograficzny, vol. 15, ed. Emanuel Rostworowski, Wrocław 1970, pp. 323-324. See more about the work and the sources used by Kromer in: Roman T. Marchwiński, Geografia Polski Marcina Kromera, Bydgoszcz 1997; idem, Ze studiów nad redakcjami „Polonii” Marcina Kromera, Komunikaty Mazursko-Warmińskie, 1994, no. 2-3, pp. 183-202; Bożena Strzelecka, Marcin Kromer, [in:] Dziewięć wieków geografii polskiej. Wybitni geografowie polscy, ed. Bolesław Olszewicz, Warszawa 1967, pp. 83-105.

${ }^{68}$ Marcin Kromer, Polska czyli o położeniu, ludności, obyczajach, urzędach i sprawach publicznych Królestwa Polskiego księgi dwie, trans. Stefan Kazikowski, ed. Roman T. MarchwiŃSKI, Olsztyn 1977, p. 53.

${ }^{69}$ Martini Cromeri Polonia sive de situ, populis, moribus, magistratibus et Republica regni Polonici libri duo, 1578, ed. Wiktor Czermak, Kraków 1901, p. 69: "Porro aromata et varia eduliorum condimenta atque cupediae, quae unacum vino et pannis aureis ac sericeis gentem hanc atque regnum vehementer exhauriunt, de longe ab oriente et occidente importantur". M. KROMER, op.cit., p. 88. 
eign visitors"70. Kromer also praises the orchards situated near Gdańsk, full of fruits as sweet as Italian fruits ${ }^{71}$, along with the abundance of fish off the coast of $\mathrm{Habu}^{72}$. Kromer also compares Gdańsk to Toruń, which he considers "not much worse, it lost to the advantage of Gdańsk and is less frequently visited"73. Gdańsk also eclipsed Elbląg, which is "perfectly fortified and rich"74.

Nicolas Wimann (Vinmann, Wynmann, 1510-1550), a Swiss humanist who left his country in connection with religious unrests, for one year held the function of the rector of the Elbląg Gymnasium (1548-1549), but here too the atmosphere of religious tolerance quickly changed, which was the reason to set out on one of his many travels ${ }^{75}$. Wimann set off on his first voyage from Gdańsk. He described the expedition in 1550 in Navigationis maris Arctoi id est Baltici et sinus Codani descriptio ${ }^{76}$. He began this journey in the port of Gdańsk, but he did not visit the city. He assessed Gdańsk through the prism of a commercial port, which he described as magnificent, to which seafood and agricultural produce were transported; he also wrote that the city dealt with trade operations efficiently ${ }^{77}$. This is only a brief reference to the description of Wisłoujście, the movement of ships and the work of sailors.

Not all the chroniclers, however, were impressed by the wealth of Gdańsk. Bernard Wapowski (1450-1535), doctor of law, a prominent cartographer and official chronicler at the court of King Sigismund I the Old, around $1535^{78}$

\footnotetext{
${ }^{70}$ Martini Cromeri Polonia, p. 43: "[...] munitione firma, civium et conucnarum industria ac diligentia culta”. M. KROMER, op.cit., p. 53.

${ }^{71}$ Martini Cromeri Polonia, p. 23; M. KROMER, op.cit., p. 28.

${ }_{72}$ Martini Cromeri Polonia, p. 31; M. Kromer, op.cit., p. 37.

${ }^{73}$ Martini Cromeri Polonia, pp. 43-44: "Gdano proxima dignitate nunc est Torunia, [...] duobusque oppidis distincta, olim emporio et omnibus rebus florentior. Sed Gdani incrementa eam non parvis detrimentis affecere et infrequentem reddidere". M. Kromer, op.cit., p. 54.

${ }^{74}$ Martini Cromeri Polonia, p. 44: "Elbinga etiam Prussiae urbs est gemina, permunita et copiosa, nisi quod eius quoque luminibus, ut ita dicam, officiunt ab altera parte Gdanum, ab altera Regius Mons sive Koenixberga, [...]”. M. Kromer, op.cit., p. 53.

${ }^{75}$ Roman DzIĘGIELEwski, Ekscentryczny szwajcarski humanista Mikołaj Wimann w Elblagu, Rocznik Elbląski, vol. 20: 2006, pp. 59-76.

${ }^{76}$ Nicolaus Vimmann, Navigationis maris arctoi id est Balthici et sinus Codani descriptio, [Speier] 1550, University Library in Toruń, Pol.6.II.1397 adl., k. nlb. 3r. Translation into Polish provided by R. DZIĘGIELEWSKI, op.cit., pp. 68-69.

${ }^{77}$ N. Vimmann, op.cit.: "Cum igitur nauim essem nactus frumentariam, XIIII primu[m] die, relicto a tergo Dantisco nobili emporio (quo scilicet diuersae \& maris \& terrarum opes importatae, facili com[m]ercio miscentur permutanturq[ae?]) secundo Vistulae alueo sic lente deferimur, ac ducentas circiter onerarias naues plenis velis aduerso flimine ascendentes mox obuias habuimus. Hae ex more effusum testabantur gaudiu[m], sibi gratula[n]tes, quod ex maris periculis tandem ereptae, ad portum diu speratum iamiam essent appulsurae".

${ }^{78} \mathrm{He}$ was appointed to the office in 1522 . He wrote the work until his death, but it was never published. The part of the work referring to the period until 1380 disappeared, while the material covering the years 1381-1463 was translated and published in the years 1847-1849,
} 
wrote about Gdańsk as the richest Pomeranian and Prussian town ${ }^{79}$, famous in the North from its marketplace (i.e. the St. Dominic's Fair) and excellent sea port ${ }^{80}$. Gdańsk is a "union of three cities" ${ }^{81}$ with strong fortifications ${ }^{82}$. About the mid-15th century Gdańsk he wrote as "famous for its resources", whose burghers were "wealthier thanks to maritime trade" 83 than burghers from other Prussian and Polish towns. The King of Poland, Sigismund I the Old, considered Gdańsk to be the finest, the most magnificent (nobilissimae) city, which is why he set out to help the city besieged by Albrecht von Brandenburg-Ansbach ${ }^{84}$. However, in another place of the chronicle he adds: "And this is not to be ignored, that all Gdańsk's vitality is drifting with the Vistula River from Poland, that the king, with one order, may cut it; completely exterminate them with hunger - the most violent, the worst of disasters" 85 .

The wealth of the city entailed the social criticism of the lifestyle of the city's inhabitants and people who visited Gdańsk. The so-called Pomerellische written down after 1525 by an anonymous author from the perspective of the dominion of the Pomeranian dynasty, is a source that has been hardly known so far. It was known to Stenzel Bornach, as evidenced by his notes left on the margins ${ }^{86}$. It was also used by Erich Keyser in his analyses of the location of

while the part of the work concerning the years 1480-1535 was published in 1874. Bernard Wapowski, Dzieje Korony Polskiej i W. Księstwa Litewskiego, vol. 1-3, ed. Mikołaj MalinowsKI, Wilno 1847-1849; idem, Chronicorum B. Vapovii pars posterior [...] Bernarda Wapowskiego z Radochoniec [...] część ostatnia czasy podługoszowe obejmująca (1480-1535), ed. Józef SzuJSKI, (Scriptores rerum Polonicarum, vol. 2), Kraków 1874. See more about the concept of the chronicle: Agnieszka Dzıuba, Wczesnorenesansowa historiografia polsko-łacińska, Lublin 2000, pp. 106-117.

${ }^{79}$ B. WAPOWski, Chronicorum, p. 178: "Gedanum opulentissimum totius Prussiae emporium $[\ldots]$...

${ }^{80}$ Idem, Dzieje Korony, vol. 1, Wilno 1847, p. 239.

${ }^{81}$ At that time the Young City of Gdańsk did not exist anymore, Wapowski probably meant here the Old Suburbs [Stare Przedmieście].

${ }^{82}$ Idem, Chronicorum, p. 178: "si forte urbem alioquin munitam [...] posset"; ibid., p. 207: "tria invicem cohaerentia Gedani oppida [...]".

${ }^{83}$ Idem, Dzieje Korony, vol. 3, Wilno 1848, pp. 318, 330.

${ }^{84}$ Idem, Chronicorum, p. 179: "At Sigismundus rex Gedani nobilissimae urbs motus periculo, facto ex omni exercitu delectu, septem bellatorum equitum millia dato stipendio conscripsit, et eos duce Nicolao Firleio palatino Sendomiriensi ad hostes Germanos persequendos, oppidaque deperdita recuperanda misit".

${ }^{85}$ Idem, Dzieje Korony, vol. 3, Wilno 1848, pp. 318-323.

${ }^{86} \mathrm{He}$ was identified by one of the owners of the codex. He bound the book and prepared the index - Archiwum Państwowe w Gdańsku [State Archives in Gdańsk] [further cit. AP Gdańsk], 300, R/Ll 9, p. 9. Comp. Erich KeYser, Die Entstehung von Danzig, Danzig 1924, p. 17, fn. 1 and 2. According to him, the content of the chronicle was known to the chroniclers of Gdańsk: Simon Grunau and Bartolomäus Wartzmann. Jolanta Dworzaczkowa was familiar with the block including the volume containing Pomerellische Chronik. Yet, the scholar failed to include the 
the duke's castle near Gdańsk ${ }^{87}$. The title reads: "How Pomerelia, or the land in which Gdańsk is located, was incorporated into Prussia"88. The fact that it is not Gdańsk that lies at the center of the narrative of the chronicler is demonstrated by the fact of the city being mentioned at the end of the list of castles and towns, just behind Tczew, Gniew, Zantyr, Nakło and Sartowice. Nevertheless, the historian devoted more attention to the city, which was not very flattering. He cited one of many opinions about the origin of the name of Gdańsk, deriving it from the inn where dances were organized also during the holidays: "[...] the duke's court, which many people call the castle, located [is - J.M.] near Gdańsk, which is also called Dantzkruge ${ }^{89}$, because the skippers come and drink honey there and dance also on holidays, but the inn has no other name than Dantziga or Dantzkrugge" ${ }^{\prime \prime}$. The seaport character of the city, in which seafarers sought good entertainment after long and dangerous journeys, contributed to this opinion.

The perspective of the description in the presented foreign accounts obviously focused on the image of the city as the dominant landscape seen by a traveler coming to the city - from the sea, the Vistula River or the land. The fortifications were the first to be seen and they were considered the main criterion testifying to the 'urbanity' of the city of Gdan'sk; however, they received different opinions. In the mid- $15^{\text {th }}$ century, the brick fortifications were not very impressive; in the eyes of Jan Długosz their defense potential was significantly reduced by the bad strategic position. At the beginning of the $16^{\text {th }}$ century, it was already assessed as strong and solid, which corresponds to the actual development of the city during this period. The geographical location was the key distinguishing feature of Gdańsk. The term 'seaport' was used by some authors interchangeably with the term 'city' (Piccolomini). The coastal location and the proximity of the Vistula River were factors that were considered to determine the fact that Gdańsk won in the trade competition with

book in her speculations about the ways of the development of Gdańsk's historiography as she considered its author not to come from Gdańsk.

${ }^{87}$ E. Keyser, op.cit., pp. 15-17. I would like to thank Prof. dr hab. Wiesław Długokęcki for the information about the chronicle.

${ }^{88}$ AP Gdańsk, 300, R/Ll 9, p. 81: "Von dem unnde wy Pomerellen, das ist das landt do Danczke ynne leyt, tzw Preussen ist kommen".

${ }^{89}$ Literally, it meant the inn where dances were organized.

${ }^{90}$ AP Gdańsk, 300, R/Ll 9, p. 81: “[...] eyn forstlich hoff, welchen vile nannten eyn schloss lagk am Hagelbergk uber Dantziga, welchs man auch nante dy Dantzkruge, wen dÿ schiffher do hin quomen unde trincken methe, unde machten tantze im feÿer tage, sunst hetten dÿ krugge keyn anderen namen, den Dantziga adder Dantzkrugge, [...]”. 
other cities in Prussia, including Torun. The diversity of overseas and domestic goods available in one place was the hallmark of the city of Gdańsk compared to other Prussian and Polish cities. The chroniclers also appreciated the speed of commercial transactions and the fame of the St. Dominic's. Extensive commercial contacts concentrated in this city-port were a source of wealth, which is predominant in the $16^{\text {th }}$ century descriptions of Gdańsk. The dynamism of urban changes that took place in this center in a short period of time (measured by the length of human life) impressed foreigners. They described a kind of 'civilizational leap', identified by them with the transition from the wooden buildings to the brick architecture. In the descriptions from the mid- $16^{\text {th }}$ century, there appears a noticeable tendency of scholars to identify the name of the city with wealth. It was the city's affluence that overshadowed other features of the city - the beauty of architecture and its size. It can be assumed that for a foreign reader these were not significant elements, and anyone who read about the rich seaside resort could easily imagine it. Everyone did it according to their own criteria, which they knew. One of such examples was shown by Sebastian Münster in Cosmographia published in 1544.

The main difference in the perspective of the description of the city of Gdańsk in the foreign and Gdańsk chronicle is primarily the described perspective. Visitors from abroad referred to the outer appearance of the center as a compact urban whole - the dominants in the landscape, which they had been able to observe a long time before they reached the resort by sea or land. They almost entirely ignored the inner-city buildings. When they referred to it, e.g. Krantz and Münster, they assessed it from the perspective of categories evaluating the degree of the city's development, i.e. the transition from thatched roofs to brick architecture. No less important was the rate at which this transformation took place. The description of buildings and city squares was, however, much more important for the Gdańsk chroniclers; in their accounts we will find references to the expansion of specific buildings and changes in interior decoration that took place during this period. They were components of the urban space, which they identified as 'home' (huse).

trans. by Agnieszka Chabros

Received 10 September 2018

Received in revised form 15 October 2018

Accepted 24 October 2018

\author{
Dr Julia Możdżeń \\ University Library in Toruń \\ e-mail: julia.mozdzen@gmail.com \\ ORCID ID: 0000-0003-4932-5546
}




\section{The Picture of the City of Gdańsk \\ in the Historiography From Beyond GdańsK in the Late \\ Middle Ages and the Beginning of the Early Modern Period}

\section{Summary}

Key words: city in the Middle Ages and in the early modern period, chronicle, historiography, travel accounts

This article places into a broader scope of the research over the image of Gdańsk and its inhabitants in chronicles that are carried out by the authoress. It deals with the analysis of the historiographical sources originating from beyond Gdańsk. The majority of chronicles' excerpts dedicated to Gdańsk deals with its political and trade activity. The authoress is particularly interested in the criteria, put forward by the chroniclers from $15^{\text {th }}$ to $16^{\text {th }} \mathrm{c}$., which decided on Gdańsk's urban character, or indicated its value as a city and made it worth a visit. It was a period of intense development of this centre. The purpose of the analyses is to, i.a., check whether the contemporary chroniclers observed these changes and how they evaluated them. The issue has not yet been addressed in the literature of the subject.

The analyses, referring to Hans Werner-Goetz's methodology concerning the representations in chronicles (so-called Vorstellungsgeschichte), were carried out on various chronicles, relations and records, i.a. travel records (Gilbert de Lannoy and Mikołaj Wimann), Polish chronicles (Annales by Jan Długosz, chronicles by Bernard Wapowski, Joachim Bielski, Polonia by Marcin Kromer), foreign chronicles Germania by Eneas Silvius Piccolomini, Wandalia by Albert Krantz), or universal chronicles (Cosmographia by Sebastian Münster). The analysis shows that in the first half of the $15^{\text {th }}$ century the contemporaneous authors did not stand out of other towns in the region (Jan Długosz, Gilbert de Lannoy, Eneas Silvius Piccolomini). Their assessment was made while they pondered on the city's fortifications, geographical location and building material. It was not until the Thirteen Years War (1454-1466) and subsequent expansion of the city that the chronicles of the 16th c. noticed the ongoing change (especially Albrecht Krantz and Sebastian Münster). They described the "civilizational leap" that took place in Gdańsk in short time, namely during the life of one man. In their opinion, the changes were particularly noticeable in the fast pace of replacing wooden buildings with brick ones.

The image of Gdańsk in the foreign chronicles does not contain elements of the descriptions of the city characteristic of Gdańsk records, which the authoress analyzed elsewhere - there are no references to specific buildings, streets and squares, that is, the living space of the city's inhabitants. 


\author{
Das Bild der Stadt Danzig in der Historiografie \\ ausserhalb Danzigs im SPÄten Mittelalter \\ UND AM BEGINN DER FRÜHEN NEUZEIT
}

\title{
Zusammenfassung
}

Schlüsselwörter: Stadt in Mittelalter und früher Neuzeit, Chronik, Historiografie, Reiseberichte

Der Artikel gehört in den größeren Zusammenhang der Forschungen, die die Autorin über das Bild der Stadt Danzig und ihrer Einwohner in der Chronistik angestellt hat. Hier geht es um eine Analyse der historiografischen Überlieferungen, die außerhalb der Stadt Danzig entstanden sind. Die klare Mehrheit der Erwähnungen dieser Stadt in den Chroniken war der Aktivität dieses Zentrums in Politik und Handel gewidmet. Vor allem interessieren die Autorin jedoch die Kriterien, die nach den Chronisten vom 15. bis zum 16. Jahrhundert über den städtischen Charakter von Danzig entschieden, d. h. dass sie dieses Zentrum als eine Stadt bewerteten und es für Neuankömmlinge attraktiv machten. Dennn dieses Zentrum machte zu dieser Zeit eine intensive Entwicklung durch. Die Analysen sollen unter anderem zeigen, ob die Zeitgenossen diese Veränderungen wahrnahmen und wie sie sie bewerteten. Dieses Problem wurde in der Literatur bisher nicht behandelt. Die Autorin bezieht sich in ihren Analysen auf die Methodologie von Hans-Werner Goetz zur Analyse sog. Vorstellungen in der Chronistik (sog. Vorstellungsgeschichte). Analysiert wurden auch verschiedene Gattungen von Chroniken, Berichte und Vermerke. Dabei handelt es sich sowohl um Berichte von Reisen, u. a. von Gilbert de Lannoy und Nikolaus Wimann, um polnische Chroniken, z. B. die Jahrbücher von Jan Długosz, die Chroniken von Bernard Wapowski und Joachim Bielski, die Polonia von Marcin Kromer, um ausländische Chroniken wie die Germania des Enea Silvio Piccolomini oder die Wandalia von Albert Krantz sowie um Weltchroniken, z. B. die Cosmographia von Sebastian Münster. Die inhaltliche Analyse der Chronikberichte zeigt, dass sich nach Ansicht der Zeitgenossen Danzig in der 1. Hälfte des 15. Jahrhunderts nicht von anderen Städten in der Region unterschied (Jan Długosz, Gilbert de Lannoy, Piccolomini). Die Urteile bildete man sich bei der Beschreibung von Befestigungen, geografischer Lage und des in der städtischen Bebauung vorherrschenden Baumaterials. Erst der Dreizehnjährige Ktieg (1454-1466) und der darauf folgende Umbau der Stadt führten dazu, dass Chronisten, die im 16. Jahrhundert schrieben, den sich vollziehenden Wandel bemerkten (vor allem Albrecht Krantz und Sebastian Münster). Der „Zivilisationssprung“, der sich in Danzig im Lauf eines Menschenlebens vollzogen hatte, wurde von ihnen bemerkt und beschrieben. Nach ihrer Meinung bestand er in dem schnellen Tempo, in dem die Bebauung aus Holz durch eine aus Stein ersetzt wurde. Das Bild Danzigs in der ausländischen Chronistik enthält nicht die Elemente der Stadtbeschreibung, wie sie in Danziger Aufzeichnungen üblich waren, die die Autorin an anderer Stelle analysiert hat; es fehlt in ihm an Hinweisen auf konkrete Gebäude, Straßen und Plätze, mithin den Lebensraum der Stadtbewohner. 
OBRAZ MIASTA GDAŃSKA W HISTORIOGRAFII POZAGDAŃSKIEJ W PÓŹNYM ŚREDNIOWIECZU I POCZĄTKACH EPOKI NOWOŻYTNEJ

\section{Streszczenie}

Słowa kluczowe: miasto średniowieczne i nowożytne, kronika, historiografia, relacje z podróży

Artykuł wpisuje się w szerszy zakres badań prowadzonych przez autorkę nad obrazem miasta Gdańska i jego mieszkańców w kronikarstwie. W prezentowanym artykule podjęto się analizy przekazów historiograficznych powstałych poza Gdańskiem. Zdecydowana większość kronikarskich wzmianek dotyczących tego miasta poświęcona była politycznej i handlowej działalności tego ośrodka. Autorkę interesują jednak przede wszystkim kryteria, które wedle kronikarzy piszących od XV do XVI w. decydowały o „miejskości” Gdańska, tj. wartościowały ten ośrodek jako miasto i sprawiały, że stawał się atrakcyjny dla przybyszów. Był to bowiem okres intensywnego rozwoju tego ośrodka. Celem analiz było m.in. sprawdzenie, czy współcześni te przemiany zaobserwowali i jak je oceniali. Jest to zagadnienie dotąd w literaturze niepodejmowane. Autorka odwołuje się w swoich badaniach do metodologii Hansa Wernera-Goetza dotyczącej analiz tzw. przedstawień w kronikarstwie (tzw. Vorstellungsgeschichte). Analizie poddano różnorodne gatunki kronikarskie, relacje i zapiski. Są to zarówno relacje z podroży, m.in. Gilberta de Lannoy i Mikołaja Wimanna; kroniki polskie, np. Roczniki Jana Długosza, kroniki Bernarda Wapowskiego, Joachima Bielskiego, Polonia Marcina Kromera; kroniki obce - Germania Eneasza Sylwiusza Piccolominiego czy Wandalia Alberta Krantza oraz kroniki świata, np. Cosmographia Sebastiana Münstera. Analiza treści kronikarskich relacji wskazuje, że Gdańsk w pierwszej połowie XV w., zdaniem współczesnych, nie wyróżniał się spośród innych miast regionu (J. Długosz, G. de Lannoy, S. E. Piccolomini). Oceny dokonywali, opisując fortyfikacje, położenie geograficzne i budulec przeważający w zabudowie miejskiej. Dopiero wojna trzynastoletnia (1454-1466) i następująca po niej rozbudowa miasta sprawiły, że kronikarze piszący w XVI w. dostrzegli dokonującą się zmianę (zwłaszcza A. Krantz i S. Münster). Dostrzegli i opisali oni „skok cywilizacyjny”, jaki dokonał się w Gdańsku w ciągu życia jednego człowieka. Polegał on ich zdaniem na szybkim tempie, w jakim zabudowa drewniana została zastąpiona murowaną. Obraz Gdańska w kronikarstwie obcym nie zawiera elementów opisu miasta charakterystycznych dla gdańskich zapisek, które autorka analizowała w innym miejscu - brakuje w nim odnośników do konkretnych budynków, ulic i placów, czyli przestrzeni życia mieszkańców miasta.

\section{BIBLIOGRAPHY}

Andermann, Ulrich. Albert Krantz. Wissenschaft und Historiographie um 1500. Weimar: Böhlau, 1999.

Arnold, Udo. "Deutschordenshistoriographie im Deutschen Reich." In Die Rolle der Ritterorden in der mittelalterlicher Kultur, edited by Zenon Hubert Nowak, 65-87. Toruń: Wydawnictwo Uniwersytetu Mikołaja Kopernika, 1985. 
Bachmann, Friedrich. Die alten Städtebilder. Ein Verzeichnis der graphischen Ortsansichten von Schedel bis Merian. Leipzig: Verlag Karl W. Hiersemann, 1939.

Barycz, Henryk. “Kromer Marcin.” In Polski Słownik Biograficzny, vol. 15, edited by Emanuel Rostworowski, 323-324. Wrocław: Wydawnictwo Zakładu Narodowego im. Ossolińskich, 1970.

Bisaha, Nancy, ed. Aeneas Silvius Piccolomini, Europe (c. 1400-1458). Translated by Robert Brown. Washington: The Catholic University of America Press, 2013.

Biskup, Marian. "Działalność dyplomatyczna Jana Długosza w sprawach pruskich w latach 1454-1466” In Dlugossiana. Studia historyczne w pięćsetlecie śmierci Jana Długosza, edited by Stanisław Gawęda, 141-167. Kraków: Państwowe Wydawnictwo Naukowe, 1980.

Biskup, Marian. Historia Torunia, vol. 2/1: U schyłku średniowiecza i w początkach odrodzenia (1454-1548). Toruń: Towarzystwo Naukowe w Toruniu, 1992.

Biskup, Marian. “Kultura.” In Historia Gdańska, vol. 1: Do roku 1454, edited by Edmund Cieślak, 446-474. Gdańsk: Wydawnictwo Morskie, 1978.

Bollbuck, Harald. Geschichts- und Raummodelle bei Albert Krantz (um 1448-1517) und David Chytraeus (1530-1600). Transformationen des historischen Diskurses im 16. Jahrhunderts. Frankfurt am Main: Peter Lang, 2006.

Buczek, Karol. "Ein Beitrag zur Entstehungsgeschichte der 'Kosmographie' von Sebastian Münster.” Imago Mundi 1 (1935): 35-40.

Bues, Almut, ed. Die Aufzeichnungen des Dominikaners Martin Gruneweg (1562 - ca. 1618) über seine Familie in Danzig, seine Handelsreisen in Osteuropa und sein Klosterleben in Polen, vol. 4: Einleitung, Beilagen, Register. Warszawa: Harrassowitz Verlag, 2008.

Bukal, Grzegorz. Fortyfikacje Gdańska i ujścia Wisty 1454-1793. Studium z dziejów nowożytnej architektury militarnej. Sopot: Grzegorz Bukal, 2012.

Cosanne, Anette. “Krantz, Albert." In Lexikon des Mittelalters, vol. 5, edited by Robert Auty, 1475. München, Zürich: Artemis Verlag, 1991.

Czermak, Wiktor, ed. Martini Cromeri Polonia sive de situ, populis, moribus, magistratibus et Republica regni Polonici libri duo, 1578. Kraków: nakł. Akademii Umiejętności, 1901.

Dąbrowski, Jan, Wanda Semkowicz-Zarembina, Krystyna Pieradzka and Bożena Modelska-Strzelecka, eds. Ioannis Dlugossii Annales seu Cronicae incliti Regni Poloniae. Liber 1-2. Varsaviae: Państwowe Wydawnictwo Naukowe, 1964.

Deptuła, Czesław. "Księdza kanonika Jana Długosza osobliwe spojrzenie na miasta Regni Poloniae." In Ecclesia - cultura - potestas. Studia z dziejów kultury i społeczeństwa, edited by Paweł Kras, 649-672. Kraków: Wydawnictwo Towarzystwa Naukowego „Societas Vistulana”, 2006.

Dworzaczkowa, Jolanta. Dziejopisarstwo gdańskie do połowy XVI wieku. Gdańsk: Gdańskie Towarzystwo Naukowe, 1962.

Dzięgielewski, Roman. "Ekscentryczny szwajcarski humanista Mikołaj Wimann w Elblągu." Rocznik Elbląski 20 (2006): 59-76.

Eco, Umberto. Sztuka i piękno w średniowieczu. Translated by Magdalena Kimula and Mikołaj Olszewski. Kraków: Znak, 1994. 
Gaebel, Georg, ed. Des Thomas Kantzow Chronik von Pommern in hochdeutscher Mundart, vol. 1-2. Stettin: Verlag von Paul Niekammer, 1897-1898.

Gause, Fritz. Die Geschichte der Stadt Königsberg in Preussen, vol. 1: Von der Gründung der Stadt bis zum letzten Kurfürsten. Köln, Weimar, Wien: Böhlau Verlag, 1996.

Gintel, Jan, ed. Cudzoziemcy o Polsce. Relacje i opinie, vol. 1: Wiek X-XVII. Kraków: Wydawnictwo Literackie, 1971.

Goetz, Hans-Werner. "Wahrnehmungs- und Deutungsmuster als methodisches Problem der Geschichtswissenschaft.” Das Mittelalter 8/2 (2003): 23-33.

Grautoff, Ferdinand Heinrich, ed. Chronik des Franciscaner Lesemeisters Detmar, nach der Urschrift und mit Ergänzungen aus andern Chroniken, vol. 1-2. Hamburg: Friedrich Berthes, 1829-1830.

Hantzsch, Viktor. Sebastian Münster. Leben, Werk, wissenschaftliche Bedeutung. Leipzig: Teubner, 1898.

Heinemann, Otto, ed. Johannes Bugenhagens Pomerania. Stettin: Verlag von Léon Saunier's Buchhandlung, 1900.

Jäger, Eckhart. Prussia-Karten 1542-1810. Geschichte der kartographischen Darstellung Ostpreußens vom 16. bis zum 19. Jahrhundert. Entstehung der Karten - Kosten Vertrieb. Bibliographischer Katalog. Weißenhorn: Anton H. Konrad Verlag, 1982.

Kaczor, Dariusz. “Orbis Gedanense. Wizja Gdańska w kronice dominikanina Martina Grunewega (XVI w.).” In Dominikanie. Gdańsk - Polska - Europa. Materiaty $z$ konferencji międzynarodowej pt. „Gdańskie i europejskie dziedzictwo. Zakon dominikanów w dziejach Gdańska", edited by Dariusz Aleksander Dekański, Andrzej Gołembnik and Marek Grubka, 549-569. Gdańsk: Dominikańskie Centrum św. Jacka, Pelplin: Wydawnictwo Diecezji Pelplińskiej „Bernardinum”, 2003.

Kantzow, Thomas. Pomerania. Kronika pomorska $z$ XVI wieku, vol. 1-2. Edited by Kszysztof Gołda, Tadeusz Białecki and Edward Rymar. Szczecin: Uniwersytet Szczeciński, Archiwum Państwowe, 2005.

Karp, Paweł. "Gdańsk w obliczu polsko-husyckiej wyprawy zbrojnej przeciw zakonowi krzyżackiemu w rok 1433.” In Florilegium historicum amicorum munera. Profesorowi Krzysztofowi Maciejowi Kowalskiemu w sześćdziesiąta piąta rocznicę urodzin, przyjaciele, koledzy, uczniowie, edited by Tomasz Maćkowski, 399-411. Gdańsk: Eko-Dom, 2016.

Keyser, Erich. Die Entstehung von Danzig. Danzig: A. W. Kafemann, 1924.

Konczyńska, Wanda. List Sebastjana Münstera do Stanisława Łaskiego i garść szczegółów w związku z jego Kosmografią. Kraków: Drukarnia W. L. Anczyca i Spółki, 1936.

Kromer, Marcin. Polska czyli o położeniu, ludności, obyczajach, urzędach i sprawach publicznych Królestwa Polskiego księgi dwie. Edited by Roman T. Michałowski and Stefan Kazikowski. Olsztyn: Pojezierze, 1977.

Krzyżaniakowa, Jadwiga. “Gdańsk w średniowiecznej historiografii polskiej.” In Gdańsk średniowieczny w świetle najnowszych badań archeologicznych i historycznych. Materiały $z$ konferencji zorganizowanej z okazji tysiaclecia Gdańska (997-1997), edited by Henryk Paner, 133-142. Gdańsk: Muzeum Archeologiczne, 1998. 
Kuczyński, Stefan Maria, ed. Lata wojny trzynastoletniej w 'Rocznikach czyli kronikach' inaczej 'Historii polskiej' Jana Długosza, (1454-1466), vol. 1. Łódź: Łódzkie Towarzystwo Wydawnicze, 1964.

Lelewel, Joachim, ed. Gilbert de Lannoy i jego podróże. Poznań: J. K. Żupański, 1844.

Maciej z Miechowa. Chronica Polonorum. Kraków: Krajowa Agencja Wydawnicza, 1986.

Marchwiński, Roman T. “Ze studiów nad redakcjami 'Polonii’ Marcina Kromera.” Komunikaty Mazursko-Warmińskie (1994) issue 2-3: 183-202.

Marchwiński, Roman T. Geografia Polski Marcina Kromera. Bydgoszcz: Wydawnictwo Uczelniane Wyższej Szkoły Pedagogicznej, 1997.

Meurer, Peter H. "Cartography in the German Lands 1450-1650." In The History of Cartography, vol. 3/2: Cartography in the European Renaissance, edited by David Woodward, 1209-1213. Chicago, London: The University of Chicago Press, 2007.

Możdżeń, Julia. “Estetyka i obronność miast w narracji Roczników Jana Długosza.” In Jan Długosz. 600-lecie urodzin. Region - Polska - Europa w jego twórczości, edited by Jacek Maciejewski, Piotr Oliński, Waldemar Rozynkowski and Sławomir Zonenberg, 85-98. Toruń, Bydgoszcz: Towarzystwo Naukowe w Toruniu, 2016.

Możdżeń, Julia. "Morze w zapiskach gdańskiego szypra Caspra Weinreicha z lat 14611496." In W epoce żaglowców. Morze od antyku do XVIII wieku, edited by Beata Możejko and Ewa Bojaruniec-Król, 69-80. Gdańsk: Wydawnictwo Uniwersytetu Gdańskiego, 2016.

Możdżeń, Julia. Przedstawianie świata przez kronikarzy gdańskich na przełomie XV i XVI wieku. Toruń: Towarzystwo Naukowe w Toruniu, 2016.

Münster, Sebastian. Cosmographia, Basel 1628. Jubiläums-Ausgabe, vol. 1-2. Edited by Karl-Heniz Burmeister. Lindau: Antiqua-Verlag, 1982.

Niewiński, Andrzej. "Podróżnik i król. Gilbert de Lannoy na dworze Władysława Jagiełły." Roczniki Humanistyczne 61/2 (2013): 25-39.

Nordmann, Viljo Adolf. Die Wandalia des Albert Krantz. Eine Untersuchung. Helsinki: Finnische Literatur-Ges., 1934.

Peliwo, Stanisław. Drzeworytowe mapy ziem polskich $w$ wydawnictwach książkowych XVI w. Warszawa: Biblioteka Narodowa, 1991.

Preisner, Claus. “Münster Sebastian.” In Neue Deutsche Biographie, vol. 18, 539-541. Berlin: Duncker \& Humblot, 1997.

Radoch, Marek. "Ziemie pruskie w oczach Gilberta de Lannoy." Komunikaty MazurskoWarmińskie (2005) issue 4: 473-484.

Rebas, Hain. "Die Reise des Ghillebert de Lannoy in den Ostseeraum 1413/14. Motive und Begleitumstände.” Hansische Geschichtsblätter 101 (1983): 30-42.

Reincke, Heinrich. "Albert Krantz als Geschichtsforscher und Geschichtsschreiber." In Festschrift der Hamburgischen Universität ihrem Ehrenrektor Herrn Bürgermeister Werner von Melle zu 80. Geburtstag am 18. Oktober 1933 dargebracht, 111-147. Glückstadt: Augustin, 1933.

Śliwiński, Błażej and Dominika Pietkiewicz, eds. Kronika Oliwska. Źródło do dziejów Pomorza Wschodniego z połowy XIV wieku. Malbork: Muzeum Zamkowe w Malborku, 2008. 
Śnieżko, Dariusz. Kronika wszytkiego świata Marcina Bielskiego. Pogranicze dyskursów. Szczecin: Wydawnictwo Naukowe Uniwersytetu Szczecińskiego, 2004.

Strehlke, Ernst, ed. "Aus den Voyaiges de Gilbert de Lannoy 1412 ff." In Scriptores rerum Prussicarum. Die Geschichtsquellen der preussischen Vorzeit. Bis zum Untergange der Ordensherrschaft, vol. 3, edited by Theodor Hirsch, Max Töppen and Ernst Strehlke, 444-452. Leipzig: Verlag von S. Hirzel, 1866.

Strzelecka, Bożena. "Marcin Kromer." In Dziewięć wieków geografii polskiej. Wybitni geografowie polscy, edited by Bolesław Olszewicz, 83-105. Warszawa: Wiedza Powszechna, 1967.

Szelińska, Wacława. Chorographia Regni Poloniae Jana Długosza. Kraków: Wydawnictwo Naukowe WSP, 1980.

Töppen, Max, ed. "Enee Silvii episcopi Senensis de situ et origine Pruthenorum.” In Scriptores rerum Prussicarum. Die Geschichtsquellen der preussischen Vorzeit. Bis zum Untergange der Ordensherrschaft, vol. 4, edited by Theodor Hirsch, Max Töppen und Ernst Strehlke, 218-231. Leipzig: Verlag von S. Hirzel, 1870.

Töppen, Max, ed. "Ex Aeneae Sylvii historia Bohemica." In Scriptores rerum Prussicarum. Die Geschichtsquellen der preussischen Vorzeit. Bis zum Untergange der Ordensherrschaft, vol. 4, edited by Theodor Hirsch, Max Töppen und Ernst Strehlke, 241-242. Leipzig: Verlag von S. Hirzel, 1870.

Tylewska-Ostrowska, Zofia and Dagmara Binkowska, eds. Gdańsk w literaturze. Bibliografia od roku 997 do dzisiaj, vol. 1: Około 998-1600. Gdańsk: słowo/obraz terytoria, 2009.

Wapowski, Bernard. Chronicorum B. Vapovii pars posterior [...] Bernarda Wapowskiego z Radochoniec [...] część ostatnia czasy podługoszowe obejmująca (1480-1535). Edited by Józef Szujski. Kraków: nakł. Akademii Umiejętności, 1874.

Wapowski, Bernard. Dzieje Korony Polskiej i W. Księstwa Litewskiego, vol. 1-3. Edited by Mikołaj Malinowski. Wilno: nakł. i czcionkami Teofila Glücksberga, 1847-1849.

Wyrozumski, Jerzy, Danuta Turkowska and Stanisław Andrzej Sroka, eds. Joannis Dlugossii Annales seu Cronicae incliti Regni Poloniae. Lib. 11. Varsaviae: Państwowe Wydawnictwo Naukowe, 2001.

Zdrenka, Joachim. Główne, Stare i Młode Miasto Gdańsk i ich patrycjat w latach 1342-1525. Toruń: Adam Marszałek, 1992. 